\title{
Role of Neuraxial Steroids in Interventional Pain Management
}

\author{
Laxmaiah Manchikanti, MD
}

The clinical introduction of cortisone in 1949 revolutionized medical care of patients with a host of diseases. Soon after that, the first use of steroids in epidural injections was described in 1952 and 1953. A variety of corticosteroid agents (hydrocortisone, methylprednisolone, triamcinolone, betamethasone) have been applied neuraxially to treat spinal pain and other types of painful conditions. The utilization of neuraxial steroids had its empirical beginning in the 1950s and '60s. When steroid administration seemingly was effective for management of low back pain and sciatica, the concept was adapted for other types of neural blockade, including facet joint injections. It is postulated that corticosteroids reduce inflammation by inhibiting either the synthesis or release of a number of pro-inflammatory substances and by causing a reversible local anesthetic effect.

Multiple complications of corticosteroid administration are

The clinical introduction of cortisone a purified glucocorticoid preparation, in 1949, revolutionized the medical care of patients with a host of diseases (1-3). Soon after this, the first use of steroids in epidural injections dating back to 1952 and 1953 was reported $(4,5)$. Simultaneous with the introduction of steroids in management of low back pain neuraxially, case reports also started appearing with the introduction of chronic glucocorticoid therapy describing life-threatening adrenal crisis in patients with medical or surgical stresses not receiving adequate corticosteroid supplementation (6, 7). The initial American report of epidural steroid injections appeared in 1961, by Goebert et al (8). Extensive use of neuraxial steroids has been described in medical practices since the introduction of steroids into the epidural space in 1952 (4), including of not only epidural steroids, but also facet joint injections $(9,10)$.

Since the introduction of neuraxial steroids, there has been

From Pain Management Center of Paducah, Paducah, Kentucky. *Dr. Manchikanti is Medical Director at the Pain Management Center of Paducah. Address correspondence: Laxmaiah Manchikanti, MD, 2831 Lone Oak Road, Paducah, KY 42003. E-mail: drm@apex.net two-fold: those resulting from withdrawal of steroids and those resulting from continued use of large doses. These include neural toxicity, separation of pituitary-adrenal axis, weight gain, osteoporosis, as well as many other complications. However, a review of the literature on epidural steroids or other types of neuraxial blockade mentions very few complications that can be directly attributed either to the chemistry or the pharmacology of the steroids, except for reports of adrenal suppression.

This review describes various aspects of neuraxial steroids including historical concepts, mechanism of action, pharmacological aspects, side effects, complications and their role in treatment.

Keywords: Neuraxial steroids, epidural steroid injections, corticosteroids, hypothalamic-pituitary-adrenal suppression, neurotoxicity, osteoporosis, deposteroids

controversy with regards to their pharmacology mechanism of action, neural toxicity and other side effects and complications.

\section{HISTORY}

The first descriptions of the use of neural blockade in managing low back and lower extremity pain date back to reports of Sicard (11), and Pasquier and Leri in 1901 (12); and Cathelin (13) in 1901 for inoperable cancer of the rectum. Caussade and Queste (14) published reports on cures of sciatica with epidural anesthesia in 1909, even without steroids. Many nerve block clinics were in operation by the 1950s $(15,16)$. The first use of steroids in epidural injections was reported by Robechhi and Capra in 1952 (4). However, the first report of the use of epidural steroid injections has been attributed by various authors to Lievre et al in 1953 (5).

Neuraxial steroids have been used in medical practices since 1952 with international literature describing their use $(4,5,8-10,15)$. In 1976, Mooney and Robertson (10) showed that the injection of local anesthetic into a facet joint could relieve the pain provoked by injection of hypertonic saline. Hypertonic saline neurolysis with injec- 
tion of corticosteroids and spinal endoscopy with adhesiolysis were developed over the years $(17,18)$.

\section{MECHANISM OF ACTION}

The utilization of steroids in neural blockade has been empirical beginning in the 1950s and 60s. They were first used for the treatment of lumbar radiculopathy at a time when the use of steroids by injection was becoming fashionable (9). When it became apparent that the injection of steroids into joints could relieve certain types of joint pain, investigators and practitioners turned their use to problems of back pain, as well as lumbar radiculopathy $(4,5,9,19)$. Subsequently, when steroid administration seemingly was effective for management of low back pain and sciatica, others followed the concept and adapted the treatment, not only for epidural administration, but also for other types of neural blockade including facet joint injections (8-10, 20-31). The search into rationale for the use of epidural steroids began retrospectively with the focus on strong antiinflammatory effects of corticosteroids (9). During this search, attractive propositions were made employing an inflammatory component in lumbosacral radiculopathy. In fact, various authors referred to the available literature that indicated that sciatica might be associated with inflammation $(9,32-48)$. No direct evidence supported the notion of inflammation and the first evidence suggesting inflammation in patients with radiculopathy only came in 1981 (25). Ryan and Taylor (25), by examining samples of cerebrospinal fluid (CSF) during administration of intrathecal and epidural injections, observed that inflammation was a critical component of radicular pain, and that intraspinal steroids were likely to be most effective when this inflammation was still acute, before the pathology had progressed to nerve root fibrosis or axonal death. These researchers classified patients into two categories: compressive and irritative radiculopathy.

Further, the rationale for neuraxial steroid use is primarily based on the benefits of neural blockade, which include pain relief which outlasts by hours, days, and sometimes weeks, the transient pharmacologic action of other adjuvant agents such as local anesthetics. However, the explanation for such benefits continues to be an enigma. It has been postulated that neural blockade alters or interrupts nociceptive input, reflex mechanism of the afferent limb, self-sustaining activity of the neuronal pools in the neuraxis, and the pattern of central neural activities (49). The basis of these explanations, in part, includes the pharmacological and physical actions of corticosteroids, as well as local anesthetics. It is postulated that corticosteroids reduce in- flammation either by inhibiting the synthesis or release of a number of pro-inflammatory substances or by causing a reversible local anesthetic effect (50-62). Various modes of action of corticosteroids include membrane stabilization, inhibition of neural peptide synthesis or action, blockade of phospholipase $\mathrm{A}_{2}$ activity, prolonged suppression of ongoing neuronal discharge, and suppression of sensitization of dorsal horn neurons. In addition to reversible local anesthetic effect, inflammation around the discs and nerve roots is considered a major pain generator with or without mechanical factors (39-48). Epidural injections of betamethasone in a model of lumbar radiculopathy showed a significant effect on thermal hyperalgesia, while administration of intravenous (IV) methylprednisolone dramatically reduced the nerve root injury produced by epidural application of autologous nucleus pulposus in a pig experimental model $(55,58)$. Minamide et al $(60)$ studying the effects of steroid and lipopolysaccharide on spontaneous resorption of herniated intervertebral discs in an experimental study in the rabbit, concluded that lipopolysaccharide accelerated the process of herniated intervertebral disc resorption, whereas high dose steroids suppressed the process. Johansson and Bennett (61) studied the effect of local methylprednisolone on pain in a nerve injury model by inducing peripheral mononeuropathy and showed that the heat hyperalgesia and mechano-allodynia, but not the mechano-hyperalgesia were depressed in the animals receiving the corticosteroids, but not in those treated with saline, with the effect remaining during the 11 day test period. Kingery et al (62) examined the effects of systemic methylprednisolone on acute nociception and on pain behavior in hyperalgesia in normal and neuropathic rats and reported that chronic steroid treatment prevented the development of neuropathic edema and completely blocked neurogenic extravasation. However, the findings also showed that corticosteroids did not affect nociceptive thresholds in normal or neuropathic hyperalgesic rats.

Some of the differences noted in the various studies of effectiveness were also attributed to the theory of Ryan and Taylor (25) to categories of irritative radiculopathy with inflammatory component, and compressive radiculopathy without inflammatory component. One commonly quoted study by Dilke et al (27), a double blind, randomized, prospective study of methylprednisolone and saline versus intraspinous ligament injection of saline, favored the use of epidural steroids, showing statistically significant improvement in the treatment group. This study was also duplicated with similar results by Ridley et al (28). However, Snoek et al (29) comparing injection of $2 \mathrm{cc}$ of methylprednisolone to $2 \mathrm{cc}$ of saline, showed no statistically 
significant difference between the two groups. These variations in results may be based on inflammatory components. Snoek et al (29) studied patients who apparently were more likely to fall into the category of compressive radiculopathy, whereas Dilke et al (27) and Ridley et al (28) included the patients who were more likely to fall into irritative radiculopathy. In addition, Abram and Hopwood (63), examining the outcome following epidural steroids in relation to primary diagnosis, observed that patients with radiculopathy were three times more likely to respond than those with a non-radicular diagnosis.

\section{PHARMACOLOGICAL ASPECTS}

Glucocorticoids are life-sustaining cholesterol derivatives produced in the zona fasciculata of the adrenal cortex under the negative feedback control of both the hypothalamus and pituitary gland, maintained by the hypothalamicpituitary-adrenal (HPA) axis. The hypothalamus produces corticotropin-releasing hormone $(\mathrm{CRH})$, which stimulates the pituitary gland to synthesize adrenocorticotropic hormone (ACTH) to signal production of cortisol, the main endogenous glucocorticoid $(1,3,64)$. Hormones play a crucial role in maintaining cell homeostasis and viability of the organism. Thus, cellular receptors for cortisol are ubiquitous in cell cytoplasm (1). Glucocorticoids are required to maintain normal carbohydrate, lipid, and protein metabolism (64). Cortisol facilitates catecholamine production and modulates beta-adrenergic receptor synthesis, regulation, coupling, and responsiveness (65). Glucocorticoids are postulated to enhance normal immune activity and wound healing, maintenance of cardiovascular integrity and cardiac contractility, and various other functions (64).

In contrast to glucocorticoids, mineralocorticoid synthesis occurs in the adrenal zona glomerulosa when stimulated by the renin-angiotensin-aldosterone system or hyperkalemia. Aldosterone, the main endogenous mineralocorticoid, facilitates sodium and potassium homeostasis and maintenance of intravascular volume $(3,66)$.

Recently it has been estimated that glucocorticoid secretions are approximately $5 \mathrm{mg} / \mathrm{m}^{2}$ per day to $10 \mathrm{mg} / \mathrm{m}^{2}$ per day of cortisol, which is apparently much less than previously reported $(67,68)$. These estimates of glucocorticoid secretion are equivalent to about 20 to $30 \mathrm{mg} /$ day of hydrocortisone or 5 to $7 \mathrm{mg} /$ day of oral prednisone. However, the synthesis of cortisol can increase 5- to 10-fold under conditions of severe stress, to a maximal level of approximately $100 \mathrm{mg} / \mathrm{m}^{2} /$ day $(3,69)$.
The study of the pharmacokinetics of the corticosteroids is complex. Following intramuscular (IM) administration, absorption of the water-soluble sodium phosphate and sodium succinate source is rapid; the rate of absorption of the lipid-soluble acetate and acetonide is much slower (70). The role of systemic absorption of epidural steroids has been explored in only a handful of reports (71-74). Janicki et al (73) reported pharmacokinetic analysis of methylprednisolone after epidural administration in rabbits, with only traces of methylprednisolone being detected at 6 and 12 hours after the administration of highest epidural dose of the drug, ie, $5 \mathrm{mg} / \mathrm{kg}$, whereas plasma methylprednisolone levels were undetectable at 24 to 72 hours after $5 \mathrm{mg} / \mathrm{kg}$ dose and at all sampling times for the epidural doses of 2.5 and $1.25 \mathrm{mg} / \mathrm{kg}$. Jacobs et al (71) studied 12 patients following administration of a single lumbar epidural steroid injection of methylprednisolone acetate, $80 \mathrm{mg}$, and found no absorption of the corticosteroid into the systemic circulation.

Corticosteroids affect almost all body systems. In pharmacologic doses, systemically administered glucocorticoids suppress the release of corticotropin (ACTH) from the pituitary; thus the adrenal cortex ceases secretion of endogenous corticosteroids, producing a secondary adrenocortical insufficiency. The degree and duration of hypothalamic-pituitary-adrenal (HPA) axis suppression produced by the drugs is highly variable among patients and depends on the dose, frequency, intervals between administration, and duration of glucocorticoid therapy (70, 7577). Even though the duration of anti-inflammatory activity of glucocorticoids approximately equals the duration of HPA-axis suppression, variations have been described (70, 75-77). A descriptive profile of commonly used epidural steroids is shown in Table 1. Following either IM or epidural administration of a single dose of triamcinolone acetonide, triamcinolone diacetate, methylprednisolone, or betamethasone sodium phosphate and betamethasone acetate suspension, HPA suppression varied from 4 days to 6 weeks $(70,75-77)$.

Maximum pharmacologic activity lags behind peak blood concentrations, suggesting that most effects of steroids result from modification of enzyme activity rather than from direct actions. This explains in part the significant corticosteroid activity following the epidural administration of steroids, even though they may or may not be detected in the blood. In pharmacologic doses, glucocorticoids decrease inflammation by stabilizing leukocyte lysosomal membranes, preventing release of destructive acid hydrolases from leukocytes; inhibiting macrophage accumula- 
Table 1. Profile of commonly used epidural steroids

\begin{tabular}{|c|c|c|c|c|c|c|c|}
\hline \multirow[b]{2}{*}{ Drug } & \multirow{2}{*}{$\begin{array}{l}\text { Equivalent } \\
\text { Dose }\end{array}$} & \multirow{2}{*}{$\begin{array}{l}\text { Epidural } \\
\text { Dose }\end{array}$} & \multirow{2}{*}{$\begin{array}{c}\text { Anti- } \\
\text { inflammatory } \\
\text { Potency }\end{array}$} & \multirow{2}{*}{$\begin{array}{c}\text { Sodium } \\
\text { Retention } \\
\text { Capacity }\end{array}$} & \multicolumn{3}{|c|}{ Duration of Adrenal Suppression } \\
\hline & & & & & IM & $\begin{array}{c}\text { Single } \\
\text { Epidural }\end{array}$ & $\begin{array}{c}\text { Three } \\
\text { Epidurals }\end{array}$ \\
\hline Hydrocortisone & $20 \mathrm{mg}$ & N/A & 1 & 1 & N/A & N/A & N/A \\
\hline $\begin{array}{l}\text { Depo-Methyl Prednisolone } \\
\text { (Depo-Medrol) }\end{array}$ & $4 \mathrm{mg}$ & $40-80 \mathrm{mg}$ & 5 & 0.5 & $1-6$ weeks & 1-3 weeks & N/A \\
\hline $\begin{array}{l}\text { Triamcinolone diacetate } \\
\text { (Aristocort) }\end{array}$ & $4 \mathrm{mg}$ & $25-50 \mathrm{mg}$ & 5 & 0 & 1-2 weeks & $1-5$ weeks & N/A \\
\hline $\begin{array}{l}\text { Triamcinolone acetonide } \\
\text { (Kenalog) }\end{array}$ & $4 \mathrm{mg}$ & $40-80 \mathrm{mg}$ & 5 & 0 & 2-6 weeks & N/A & 2-3 months \\
\hline $\begin{array}{l}\text { Betamethasone } \\
\text { (Celestone Soluspan) }\end{array}$ & $0.6 \mathrm{mg}$ & $6-12 \mathrm{mg}$ & 25 & 0 & 1-2 weeks & N/A & N/A \\
\hline
\end{tabular}

tion in inflamed areas; reducing leukocyte adhesion to the capillary endothelium; reducing capillary wall permeability and edema formation; decreasing complement components; antagonizing histamine activity, and release of kinin from substrates; reducing fibroblast proliferation, collagen deposition, and subsequent scar tissue formation; and possibly by other mechanisms as yet unknown (70).

Even though many clinicians believe that the duration of corticosteroid therapy, the highest corticosteroid dose, and the total cumulative corticosteroid dose are important predictors of HPA axis suppression, there are inconsistent data to accurately predict the degree of adrenal suppression in patients receiving exogenous glucocorticoid therapy. Further, recent literature suggests that patients who receive $5 \mathrm{mg}$ /day or less of prednisone continue to have an intact HPA axis (78). However, the recovery of the HPA axis after the discontinuation of exogenous glucocorticoids may take up to a year (69). Measure of plasma cortisol levels when patients are not receiving exogenous glucocorticoids and judicious application of adrenal stimulation with a lowor high-dose cosyntropin stimulation test are recommended on an individual basis to determine HPA axis reserve in persons with adrenal suppression secondary to glucocorticoid therapy $(2,79)$. However, patients with adrenal suppression secondary to corticosteroid drug therapy usually have intact mineralocorticoid function via the renin-angiotensin-aldosterone system (1).

\section{SIDE EFFECTS}

The review of the literature on epidural steroids or other types of neural blockade mentions very few complications that can be directly attributed either to the chemistry or the pharmacology of the steroids (9). Numerous formulations of injectable preparations are available in the United States and other countries. The most commonly used agents for administration in neural blockade in the United States are methylprednisolone acetate (Depo-Medrol $\left.{ }^{\circledR}\right)$, triamcinolone diacetate (Aristocort ${ }^{\circledR}$ ), triamcinolone acetonide (Kenalog ${ }^{\circledR}$ ) and betamethasone acetate and phosphate mixture (Celestone ${ }^{\circledR}$ Soluspan ${ }^{\circledR}$ ). These formulations available for injectable steroids contain various chemicals, which include buffers, polyethylene glycol, benzyl alcohol, and benzalkonium chloride (Table 2).

Nelson (80) spearheaded a crusade against intraspinal therapy using steroids and argued that methylprednisolone acetate was neurotoxic. The controversy prompted a review of the literature concerning epidural steroids (81-83). These reviews found that epidural steroids had been used extensively throughout the world, with the majority of published medical opinions supporting their use. However, although two of the reviewers $(82,83)$ recognized that intrathecal injections of steroids could result in nerve damage, but both reviewers referred to the available literature attesting to the chemical safety of corticosteroid preparations used in the epidural space. Subsequently, Bogduk et al (9) in a 1994 review concluded that there was no evidence of any deleterious effect of steroid preparations provided they were injected accurately into the epidural space, but also that none of the commercially available formulations of steroids was free of at least some potential risk of deleterious effects if it was to be injected deliberately or 
Table 2. Formulations of commonly used epidural steroids

\begin{tabular}{|c|c|c|c|c|c|c|}
\hline & \multicolumn{3}{|c|}{$\begin{array}{c}\text { Depo-Medrol } \\
\text { Methylpredisolone }\end{array}$} & $\begin{array}{c}\text { Aristocort } \\
\text { Triamcinolone } \\
\text { Diacetate }\end{array}$ & $\begin{array}{c}\text { Kenalog } \\
\text { Triamcinolone } \\
\text { Acetonide }\end{array}$ & $\begin{array}{c}\text { Celestone } \\
\text { Betamethasone }\end{array}$ \\
\hline Amount of steroid & $20 \mathrm{mg} / \mathrm{mL}$ & $40 \mathrm{mg} / \mathrm{mL}$ & $80 \mathrm{mg} / \mathrm{mL}$ & $40 \mathrm{mg} / \mathrm{mL}$ & $40 \mathrm{mg} / \mathrm{mL}$ & $6 \mathrm{mg} / \mathrm{mL}$ \\
\hline Polyethylene glycol 3350 & 29.5 & 29.1 & 28.2 & 30 & -- & -- \\
\hline Polysorbate 80 & 1.97 & 1.94 & 1.88 & 2 & 0.4 & -- \\
\hline Monobasic sodium phosphate & 6.9 & 6.8 & 6.59 & -- & -- & 3.4 \\
\hline Benzyl alcohol & 9.3 & 9.16 & 8.8 & 9 & 9 & -- \\
\hline Diabasic sodium phospate & -- & -- & -- & -- & -- & 7.1 \\
\hline Edetate disodium & -- & -- & -- & -- & -- & 0.1 \\
\hline Benzalkonium chloride & -- & -- & -- & -- & -- & 0.2 \\
\hline
\end{tabular}

inadvertently into the intrathecal space. This report, however, cautioned that the use of any steroid preparation intended for epidural injection should be accompanied by the utmost precautions to ensure accurate epidural injection and to preclude intrathecal injection. Wilkinson (81) in 1992 reviewed the literature on intrathecal Depomedrol and concluded that there was as yet no scientifically valid proof that intrathecal Depomedrol, in doses of $40 \mathrm{mg} / \mathrm{mL}$ or $80 \mathrm{mg} / \mathrm{mL}$ administered at widely spaced intervals, caused clinically significant lumbar adhesive arachnoiditis.

Various arguments of steroid toxicity to the nerves stem from potential toxicity of multiple chemical entities used in the formulations of epidural steroids, namely, benzyl alcohol, polyethylene glycol, polysorbate, monobasic and dibasic sodium phosphate, and benzalkonium chloride. Polyethylene glycol 3350 is used with Depomedrol, and Aristocort. However, it appears that various impressions of neurotoxicity of polyethylene glycol stem from the misinterpretation of studies of propylene glycol (84-88). With the use of $3 \%$ polyethylene glycol, no impairment of neural function was seen after 30 minute applications to rabbit vagus nerves (88). Benzon et al (88) also showed that only the higher concentrations altered compound action potentials or delayed conduction velocities, and those effects were rapidly reversible. They concluded that in clinically used concentrations, polyethylene glycol "does not cause neurolysis."

The ingredient with substantial controversy is benzyl alcohol which is used in vials of Depomedrol, Aristocort and Kenalog; however, not with Celestone Soluspan. On intrathecal administration of benzyl alcohol, flaccid paraplegia, leg paralysis, and neural degeneration, as well as demyelination were reported with $5 \mathrm{~mL}$ of bacteriostatic water, $40 \mathrm{~mL}$ of normal saline containing $1.5 \%$ benzyl alcohol, and $20 \mathrm{~mL}$ of methotrexate injection containing $0.9 \%$ benzyl alcohol (89-93). However, no studies have been reported with epidural usage of less than $1 \%$ of benzyl alcohol. Polysorbates were reported to have no adverse effects when given intrathecally (9). Edetate disodium (EDTA), which is used in extremely small doses (0.1 $\mathrm{mg} / \mathrm{ml}$ ) with Celestone Soluspan has been shown to induce convulsive activity in higher doses in mice when given by spinal injection (94). Benzalkonium chloride used in Celestone Soluspan formulations $(0.2 \mathrm{mg} / \mathrm{mL})$, has been used experimentally as a neurotoxin in the alimentary tract in much higher concentrations than used in Celestone $(95,96)$. However, there are no reports showing the effects of benzalkonium chloride either on peripheral nerves, nerve roots, or spinal cord. Latham et al (97) assessed the pathological effects of intrathecal betamethasone and reported that, when injected deliberately into the subarachnoid space in sheep, Celestone caused no reaction in the meninges or neural structures when small doses of $1 \mathrm{~mL}$ were used, even on repeated occasions.

Abram et al (98) studied the analgesic neurotoxic effects of either methylprednisolone sodium succinate or triamcinolone diacetate with a single dose or with chronic administration with multiple injections. They concluded that intrathecal steroid injections have no analgesic effect and do not suppress spinal sensitization when administered acutely. In addition, they noted that repeated intrathecal administration of triamcinolone diacetate $(0.5 \mathrm{mg} / \mathrm{kg})$ is not asso- 
ciated with spinal neurotoxic effects during the time period studied in rats. Delaney et al (99) studied the effects of epidural steroids on nerves and meninges in cats, utilizing triamcinolone diacetate, and concluded that all histologic findings were found to be mild and that local anestheticsteroid combinations did not cause significant damage to neural tissues. Cicala et al (100) also reported that methylprednisolone acetate failed to cause inflammatory changes in the epidural space, in adult white rabbits. They also reported that all animals that received epidural injections of normal saline containing talc had marked infiltration of tissue macrophages in the epidural space, while the animals that received either lactated Ringers solution or lidocaine with methylprednisolone acetate, revealed no white cell infiltrates and no fibroblastic activity. Consequently, they concluded that the complete lack of inflammatory changes and meningeal thickening helped to confirm the safety of the methylprednisolone acetate when injected into the epidural space. MacKinnon et al (101) investigated the effect of various types of steroids in rats by injecting either into the sciatic nerve or near the sciatic nerve. The results of this study suggested that steroids do, indeed, have neurotoxic effects, with the caveat that the site of injection is critical. The agent must be delivered directly into the nerve fascicle in order to exert any neural toxic effects. Injections of steroid agents made into the extrafascicular epidural tissue caused no nerve damage. The degree of injury also varied considerably depending on the agent used. While those nerves injected with dexamethasone (Decadron ${ }^{\circledR}$ ) showed minimal damage, those nerves injected with triamcinolone hexacetonide $\left(\right.$ Aristospan ${ }^{\circledR}$ ) and hydrocortisone (Solu-Cortef ${ }^{\circledR}$ ) showed severe widespread axonal degeneration affecting both the large and small fiber populations. In contrast, triamcinolone acetonide (Kenalog) and methylprednisolone (DepoMedrol) presented a histologic picture intermediary between the injury patterns described above. In addition, the damage with these two agents was often focal, with only part of the nerve fascicle demonstrating nerve fiber injury. The smaller fibers were relatively spared by these agents. Electron microscopic observations also revealed the most severe damage with triamcinolone acetonide (Aristospan) and hydrocortisone (Solu-Cortef). Hence, the mechanism of injury has been attributed to direct neurotoxic effect on the peripheral nerve tissue of the steroid agents, as well as direct needle injury to the nerve, ischemia, scarring, and allergic phenomenon (101).

Abram and O'Connor (102), in reviewing the risks of complications from epidural steroid injections in approximately 7,000 patients, were unable to find a single report of arach- noiditis. Following the extensive review, Bogduk et al (9) concluded that, despite what has been published, none of the literature provides direct evidence of neurotoxicity of steroids or their preservatives when injected intrathecally in the lumbar region away from the brain. In addition, it was also shown that epidural phenol, as well as intrathecal lidocaine, was neurotoxic $(103,104)$. Hashimoto et al (103) evaluated the comparative toxicity of $10 \%$ glucose and 5\% lidocaine administered intrathecally in the rat, with a control group receiving infusion of normal saline. The results showed that the lidocaine-treated animals exhibited persistent sensory impairment, whereas glucose and salinetreated animals did not; and that the histologic changes in glucose and saline-treated animals were minimal. Katz et al (104) studied histopathologic changes in the primate spinal cord after single and repeated epidural phenol administration with injection of $0.5 \mathrm{~mL}$ of either $3 \%$ phenol in saline or $6 \%$ phenol in saline via lumbar epidural injection. They also studied some primates receiving three consecutive daily epidural doses of $0.5 \mathrm{~mL}$ of $3 \%$ phenol in saline and concluded that motor weakness, anterior root damage, and direct cord injury were noted in primates following epidural administration of phenol in concentrations of $3 \%$.

Other complications of corticosteroid administration are two-fold: those resulting from withdrawal and those resulting from continued use of large doses. These include suppression of the pituitary-adrenal axis, weight gain, osteoporosis, and multiple other complications as listed in Table 3. Most of these complications are related to oral, IM, and IV adminstration of corticosteroids, even though some of these complications have been reported following utilization of steroids in neural blockade.

Side effects and complications related to the endocrine system with adrenal suppression and subsequent complications have been the major focus of neuraxial steroids. The use of corticosteroids repeatedly for days or even a few weeks does not lead to adrenal insufficiency upon cessation of treatment, but prolonged therapy with corticosteroids may result in suppression of pituitary-adrenal function that can be slow in returning to normal. The HPA axis suppression during corticosteroid therapy and after its withdrawal has been extensively studied (70, 75-77, 105-111). Knight and Burnell (106) reported the appearance of systemic side effects in four cases after each had received an injection of a total of $80 \mathrm{mg}$ to $600 \mathrm{mg}$ of methylprednisolone over a 2- or 3- day period. They reported this as a $2.2 \%$ incidence with 4 cases out of 181 lumbar extradural injections with symptoms of malaise, facial swelling, flat- 
Table 3. Potential side effects or complications of epidural steroid administration

i.

\section{Endocrine}

Adrenal suppression

Hypercorticism

Cushingoid syndrome

Hyperglycemia

Precipitation of diabetes mellitus

Immunosuppression

Hypokalemia

Amenorrhea

Menstrual disturbances

Retardation of growth

ii. Cardiovascular

Hypertension

Fluid retention

Congestive heart failure

Deep vein thrombosis

iii. Musculoskeletal

Osteopenia/osteoporosis

Avascular necrosis of bone

Pathologic fracture

Muscle wasting and atrophy

Muscle pain

Joint pain

iv. Psychological

Mood swings
Insomnia
Psychosis
Anxiety
Euphoria
Depression

v. Gastrointestinal

Ulcerative esophagitis

Hyperacidity

Peptic ulceration

Gastric hemorrhage

Diarrhea

Constipation vi.

\section{Ocular}

Retinal hemorrhage

Posterior subscapular cataracts

Increased intraocular pressure

Exophthalmus

Glaucoma

Damage to optic nerve

Secondary fungal and viral infection

vii. Dermatologic

Facial flushing

Impaired wound healing

Hirsutism

Petechiae

Ecchymosis

Hives

Dermatitis

Hyperpigmentation

Hypopigmentation

Cutaneous atrophy

Sterile abscess

viii. Metabolic

Hyperglycemia

Glycosuria

Redistribution of fat

Negative nitrogen balance

Sodium and water retention

ix. Nervous system effects

Headache

Vertigo

Insomnia

Restlessness

Increased motor activity

Ischemic neuropathy

Seizures

x. Other adverse effects

Epidural lipomatosis

Fever tening of face, scaly lesions of scalp, and a hump between the shoulder blades. Stambough et al (107) reported a case of transient hypercorticism after epidural steroid injection of $80 \mathrm{mg}$ of methylprednisolone acetate with two doses 1 week apart, which resolved in 6 weeks. Tuel et al (108) also reported Cushing's syndrome from $60 \mathrm{mg}$ of cervical epidural methylprednisolone, which reversed to baseline by 4 months. Edmonds et al (109) reported Cushing's syndrome with adrenal suppression in three patients following paraspinal depo-corticosteroid injections. These reports 
indicated that pharmacologic doses of exogenous corticosteroids suppressed the HPA axis by inhibiting ACTH secretion.

Adrenal insufficiency may be an acute or chronic primary, secondary to tertiary process $(1,3,112,113)$. Among these, tertiary adrenal insufficiency secondary to corticosteroid drug therapy is the most common type. Primary adrenal suppression is relatively rare but develops in patients who have greater than $90 \%$ destruction or replacement of the adrenal glands with inflammation, tumor, infection, or hemorrhage $(1,3,112)$. Secondary adrenal suppression is also uncommon and is secondary to pituitary dysfunction or failure with insufficient ACTZ production (1). Patients with primary adrenal suppression are both glucocorticoid and mineralocorticoid deficient. Autoimmune diseases are the most common etiology of primary adrenal insufficiency. However, therapeutic glucocorticoid administration is the most common cause of adrenal suppression (Table 4). The mechanism is that the CRH and ACTH stimulation of the adrenal gland is suppressed by an ample quantity of glucocorticoid administered for a sufficient period $(1,3,112)$. Thus, tertiary iatrogenic adrenal suppression results as the adrenal gland atrophies with time. A reduced response to exogenous ACTH has been reported by some to last for 5 days after discontinuation of oral prednisone of $25 \mathrm{mg}$ twice a day for as brief a period as 5 days (113). However, recent literature reveals that patients who receive $5 \mathrm{mg}$ /day or less of prednisone continue to have an intact HPA axis (78). Recovery of the HPA axis after the discontinuation

Table 4. Characteristics of adrenal insufficiency

\begin{tabular}{|c|c|c|}
\hline Type & Etiologies & Features \\
\hline $\begin{array}{l}\text { Tertiary } \\
\text { Most common } \\
\text { form }\end{array}$ & $\begin{array}{l}\text { Usually from iatrogenic corticosteroid therapy and } \\
\text { suppression of the hypothalamic-pituitary- } \\
\text { adrenal } \\
\text { axis }\end{array}$ & $\begin{array}{l}\text { Hypothalamic/pituitary suppression or } \\
\text { absence }\end{array}$ \\
\hline \multirow[t]{4}{*}{$\begin{array}{l}\text { Secondary } \\
\text { Uncommon }\end{array}$} & $\begin{array}{l}\text { Decreased or absent ACTH (may be } \\
\text { panhypopituitary or anterior pituitary } \\
\text { dysfunction) }\end{array}$ & ACTH dependent \\
\hline & Pituitary depression, dysfunction/damage & $\begin{array}{l}\text { Signs and symptoms usually due to } \\
\text { loss of glucocorticoid function }\end{array}$ \\
\hline & Tumor, postpartum & $\begin{array}{l}\text { Usually have intact mineralocorticoid } \\
\text { function }\end{array}$ \\
\hline & & $\begin{array}{l}\text { Renal hypovolemic, more commonly } \\
\text { hypoglycemic }\end{array}$ \\
\hline \multirow[t]{5}{*}{$\begin{array}{l}\text { Primary } \\
\text { Rare }\end{array}$} & $\begin{array}{l}\text { Autoimmune }(70 \%-90 \% \text { of cases in United } \\
\text { States), } \\
\quad \text { frequently associated with a polyglandular } \\
\text { deficiency syndrome } \\
\text { Prevalence: } \\
\quad 40-110 \text { cases/million }\end{array}$ & $\begin{array}{l}\text { ACTH independent } \\
\text { Adrenal gland dysfunction, destruction, or } \\
\text { replacement; requires }>90 \% \text { loss of adrenal } \\
\text { tissue } \\
\text { Loss of mineralocorticoid and glucocorticoid } \\
\text { production }\end{array}$ \\
\hline & $\begin{array}{l}\text { Infection } \\
\text { HIV is the most common infectious cause in the } \\
\text { United States. } \\
\text { Al develops in } 30 \% \text { of patients with advanced } \\
\text { AIDS. } \\
\text { Tuberculosis is the most common infectious } \\
\text { cause } \\
\text { worldwide }\end{array}$ & Increased ACTH production \\
\hline & Inflammation & May be hyperpigmented \\
\hline & Cancer (breast, lung, melanoma most common) & Requires lifetime therapy \\
\hline & $\begin{array}{l}\text { Acute addisonian crisis } \\
\text { Incidence: } \\
\quad 6 \text { cases/million per year }\end{array}$ & \\
\hline
\end{tabular}


of exogenous glucocorticoids may take as long as a year (69). Even though many clinicians believe that the duration of corticosteroid therapy, the highest corticosteroid dosage, and the total cumulative corticosteroid dose are important predictors of HPA axis suppression, there are inconsistent data to accurately predict the degree of adrenal suppression in patients receiving exogenous glucocorticoid therapy (1).

Kay et al (72) studied 14 patients by measurement of plasma $\mathrm{ACTH}$ and evaluation of the additional impact of sedation with midazolam before the epidural steroid injection on the degree of suppression of the hypothalamic-pituitary adrenal (HPA) axis. They concluded that weekly epidural steroid injections over a 3 week period caused a dramatic, acute, and chronic suppression of the HPA axis, with median suppression of less than 1 month and all patients recovering by 3 months. They also concluded that sedation with midazolam accentuated the suppression of the HPA axis. Hsu et al (74) also compared plasma cortisol and ACTH profiles, concluding that a single epidural injection of $40 \mathrm{mg}$ of triamcinolone markedly decreased plasma cortisol for only 24 hours; whereas $80 \mathrm{mg}$ of triamcinolone showed decreases up to 14 days post treatment, with HPA axis function returning to normal at 35 days in both groups.

Findings similar to those of epidural steroid injections have been reported after single dose intra-articular and multiple IM injections of methylprednisolone acetate, triamcinolone acetonide, and dexamethasone acetate $(110,111)$. Armstrong et al (110) showed that a single intraarticular injection of methylprednisolone acetate into the knee suppressed plasma cortisol levels for one week. Others (75, $76,111)$ have shown that a single injection of $40 \mathrm{mg}$ of triamcinolone acetonide and multiple IM injections totaling $56 \mathrm{mg}$ of dexamethazone acetate suppressed plasma cortisol levels for approximately 4 weeks. Mikahail et al $(75,76)$ reported that maintenance of adequate endogenous adrenal function was influenced by the length of interval between steroid injections at more frequent intervals than once in 6 weeks with triamcinolone acetonide (Kenalog), while suppression with $50 \mathrm{mg}$ of triamcinolone diacetate (Aristocort), or $9 \mathrm{mg}$ of betamethasone acetate - phosphate mixture (Celestone Soluspan) lasted only 1 week. The commonly administered depo-preparations for facet joint blocks, epidural injections, and other nerve blocks include triamcinolone diacetate and acetonide (Aristocort and Kenalog), methylprednisolone (Depomedrol), and betamethasone acetate - phosphate mixture (Celestone Soluspan). Discussions about these procedures empha- sizes the individual preference for therapeutic regimens. Saberski et al (114) examined the practice patterns in the use of epidural corticosteroid injections and showed that steroid usage varied with preference for methylprednisolone by $82 \%$ of practitioners, triamcinolone by $13 \%$ of the practitioners, and betamethasone by $5 \%$ of the practitioners. Thirteen different maximum steroid doses per year were offered ranging from $150 \mathrm{mg}$ to $960 \mathrm{mg}$ using conversion to methylprednisolone. Other reports indicated administration of $10 \mathrm{mg}$ of methylprednisolone acetate per level for facet joint injections and 80 to $120 \mathrm{mg}$ of methylprednisolone acetate or $80 \mathrm{mg}$ of triamcinolone diacetate each week for epidural injections $(30,31,115)$. It is also believed that triamcinolone acetonide (Kenalog) is the least water soluble and, therefore possesses the longest duration of anti-inflammatory effect and greatest suppression of the HPA axis $(109,116)$. However, review of pharmacology indicates that there is no difference between the anti-inflammatory potency of either Depomedrol, Kenalog, or Aristocort $(70,75-77,105)$. Pharmacological review also shows that betamethasone acetate - phosphate mixture (Celestone Soluspan) has five times more anti-inflammatory potency $(70,75-77,105)$. Hence, "equivalent dosages" are only general approximations, and the duration of HPA-axis suppression and degree of mineralocorticoid activities differ substantially at equivalent dosages. Triamcinolone, either in the form of diacetate or acetonide, also contains benzyl alcohol, which may be blamed for adverse reactions. Single dose vials of Depomedrol and single and multidose vials of Celestone Soluspan do not contain benzyl alcohol. Benzyl alcohol may become a major concern considering the unintended possibilities of intrathecal injections (though extremely rare) following epidural injections. It was also shown by Mikhail et al (75, 76) that adrenal suppression developed in patients receiving IM triamcinolone acetonide either every 2 or 4 weeks, whereas this did not occur in patients receiving injections every 6 weeks. In studies of methylprednisolone acetate, $40 \mathrm{mg}$ injected into two knees produced higher levels of prednisolone than $80 \mathrm{mg}$ injected into a single joint (110).

Osteoporosis and vertebral compression fractures are frequent serious complications of corticosteroid therapy in patients of all ages. Ribs and vertebrae, and bones with a high degree of trabecular structure are generally the most severely affected. The physiology of glucocorticoid-induced osteoporosis is explained by disruption of calcium balance, and decrease in calcium supply by reducing intestinal and renal tubular absorption (117). While most steroid effects on calcium absorption are dose dependent, multiple other factors subject to broader influences also 
influence calcium metabolism in osteoporosis. Ho (118) reported that corticosteroid therapy is associated with bone loss and an increased risk for fractures. However, not all patients receiving corticosteroid therapy have low bone mineral density (BMD). Thus, it is possible that there may be genetic factors placing some individuals at reduced or increased risk for bone loss following exposure to corticosteroid therapy. Associations between polymorphisms of the vitamin D receptor gene, bone mass density and intestinal calcium absorption have been reported in some studies (119-128), whereas others have reported lack of such correlation (118, 129-133). Since chronic glucocorticoid therapy is widely prescribed for patients with chronic noninfectious inflammatory diseases such as asthma, chronic lung disease, rheumatoid arthritis, and other connective tissue diseases, apart from neuraxial steroids, the issue has become an important aspect in glucocorticoid therapy. Secondary osteoporosis due to glucocorticoid therapy has been reported consistently following oral prednisone, and high doses of inhaled glucocorticoids, even though the risk appears to be lower with inhaled glucocorticoids than that associated with oral glucocorticoids. Glucocorticoid therapy induces bone loss by stimulating osteoclast-mediated bone resorption and reducing osteoblastmediated bone formation, and through direct effects on calcium metabolism and sex hormones. The risk of glucocorticoid-induced bone loss shows correlation to dosage and duration of treatment, with the greatest rate of bone loss in the first 6 months. Further, it has been postulated that the total lifetime cumulative dose may also affect the extent of bone demineralization. Of asthma patients treated with oral glucocorticoids for more than 1 year, $86 \%$ demonstrated a decrease in BMD at the hip or lumbar spine; decreases in BMD were dose-related and observed in $80 \%$ of high dose, $71 \%$ of medium-dose, and $33 \%$ of the lowdose patients (134). Glucocorticoid-induced bone loss in chronic destructive pulmonary disease has also been reported as quite high. The evaluation of bone loss among long-term corticosteroid users, involving 147 patients receiving a mean prednisone dose of $10 \mathrm{mg} /$ day for an average of 1 to 2 years showed that only $29 \%$ reported having a bone density test, $29 \%$ were taking calcium supplements and $45 \%$ were receiving vitamin $\mathrm{D}$ (135). It was also shown that there was a two-fold increased frequency of osteoporosis in all age groups of rheumatoid arthritis patients (136). Among the various predictors of reduced bone mass density were current use of corticosteroids, along with other factors, which included older age, low body weight, and greater physical disability.

Osteoporosis following steroids in neural blockade used in management of chronic pain, even though a frequently discussed problem, is uncommon. Major risk factors for glucocorticoid induced osteoporosis include total cumulative dose of glucocorticoid, ages less than 15 years or greater than 65 years and post-menopausal status (117). Aseptic necrosis of the bone (osteonecrosis) may also complicate long-term therapy with glucocorticoids and has also been reported following short courses with high doses. The femoral head is most often involved, but other large joints may be affected $(137,138)$. However, at this time, no studies show such a relationship between steroids utilized in neural blockade and osteoporosis or avascular necrosis. Preventive measures of steroid induced osteoporosis or osteonecrosis include: dose minimization, utilization of alternative therapeutic modalities and drugs, and aggressive monitoring and management (117). However, once evidence of osteoporosis has been established, the steroids should be stopped unless the benefits enormously outweigh the risks. Manchikanti et al (139) evaluated the effect of neuraxial steroids on weight and bone mass density (BMD) prospectively. They concluded that low-dose neuraxial steroids are safe in patients with chronic pain who have failed to respond to conservative modalities of treatments with a favorable risk-benefit ratio, without any deleterious effects, either on body weight or BMD.

Cousins (140) reported that an additional potential complication of administration of depo-corticosteroids related to inadvertent intravascular administration, producing occlusion of small end arteries which resulted in visual defects in one case (141) and hearing loss in another case involving suboccipital nerve block. Abram (142) also acknowledged the potential for harm from occlusion of smallend arteries by steroid suspensions. Abram (142) felt that prednisolone acetate tends to form aggregates of the steroid material when mixed with local anesthetic and may pose more of a risk for this problem than other depo-steroids. However, preparation of either methylprednisolone or triamcinolone could produce devastating consequences if injected into a spinal artery. In this aspect, betamethasone appears to be the safest, as it is most soluble with local anesthetic.

Fluid retention leading to congestive cardiac failure has been noted in the literature, but appears to be extremely rare. Sodium retention is more commonly seen with methylprednisolone rather than triamcinolone or betamethasone.

Adverse gastrointestinal effects of corticosteroids include nausea; vomiting; and anorexia which may result in weight loss; or increased appetite which may result in weight gain; 
diarrhea or constipation; abdominal distention; pancreatitis; gastric irritation; and ulcerative esophagitis. In addition, corticosteroids have been implicated in the development, reactivation, perforation, hemorrhage, and delayed healing of peptic ulcers. However, only minor digestive disturbances were reported following epidural administration of steroids $(30,31)$.

Muscle wasting, muscle pain or weakness, and delayed wound healing have been reported, manifestations of protein catabolism that may occur during prolonged therapy with glucocorticoids (143-147). These adverse effects may be especially serious in debilitated geriatric patients. Steroid induced myopathy and articular tenderness were reported in patients on long term steroid therapy $(145,146)$. However, only a single case of steroid myopathy following a single dose epidural injection of triamcinolone has been reported thus far (147).

Symptomatic spinal epidural lipomatosis induced by longterm steroid treatment causing dural or cauda equina compression has been reported (148-151). Roy-Camille et al (148) reported two cases of symptomatic epidural lipomatosis following 103 epidural injections of $40 \mathrm{mg}$ of methylprednisolone acetate in a paraplegic and after oral steroid treatment in another patient. Other cases of epidural lipomatosis include reports of five cases by Fessler et al (150) which were related to long term corticosteroid administration and by Rawlins and Di Giacinto (151) with one patient with cauda equina compression caused by epidural adipose tissue, with no history of steroid use or obvious evidence of an underlying endocrinopathy. Rare cases of congenital lipomatosis have been reported (149).

Prolonged use of glucocorticoids may result in posterior subcapsular cataracts (particularly in children), exophthalmus, or increased intraocular pressure, which may result in glaucoma or may occasionally damage the optic nerve (70, 152-162). Enhancement or establishment of secondary fungal and viral infections of the eye along with rare blindness following intralesional injection of glucocorticoids around the face and head is a possibility. The clinical reports showed that corticosteroid use may cause cataracts in approximately $5 \%$ to $60 \%$ of patients, particularly bilateral posterior subcapsular cataracts $(154,155)$. However, most of the studies involved patients with asthma, rheumatoid arthritis, or systemic lupus erythematosus, or those who had undergone renal transplantation $(156,157)$. Even though systemic corticosteroid use is most often implicated, there also have been other reports involving the topical, articular, and inhaled routes of administration (158,
159). Various risk factors for cataract formation include diabetes, myopathy, glaucoma, alcohol consumption, heavy cigarette smoking, low nutrition levels of protein, low intake of antioxidant vitamins, exposure to ultraviolet radiation, family history of cataracts, female gender, dark brown or hazel eyes, and prolonged or long term administration of various drugs including corticosteroids, nifedipine, and spironolactone (160-162). Some studies have reported highly significant correlation between cataract formation and long-term high dose administration of steroids, whereas other studies failed to demonstrate such a conclusive relationship, indicating that individual variability and susceptibility may play a more important role than total dosage or duration of administration (157, 163-166). Vision loss following epidural injections either with or without steroid has been reported (167). Kushner and Olsen (168) evaluated patients who complained of visual field defects or blurred vision after receiving the epidural steroid injection and concluded that retinal hemorrhage is an uncommon, but significant and previously unemphasized complication of epidural steroid injection. Retinal hemorrhages mainly have been attributed to rapid epidural injections of high volumes, causing a sudden increase in intracranial pressure resulting in the increase of retinal venous pressure (167-173). Based on the available literature, it appears that this complication has no relation to the steroid administration, which in fact may result with the administration of normal saline, local anesthetic, or any other type of drug. Other complications of steroids in neural blockade include: facial flushing (174), Kaposi's sarcoma (175), subdural intracranial air with headache (176), and chemical meningism (177). Methylprednisolone acetate was shown to cause degeneration and primary calcification in discs of rabbits following intradiscal steroid injection of methylprednisolone acetate and its vehicle polyethylene glycol (178).

Paradoxical reports of the development of Guillain-Barré syndrome (GBS) have been reported in patients being treated with corticosteroids (179). In published cases (179, 180), the onset of GBS was associated with rapid tapering of corticosteroid regimens. However, treatment with hydrocortisone (400 $\mathrm{mg}$ per day) resulted in great improvement. GBS was also reported in a patient with hereditary angioedema and a wire-loop lesion of the kidney (which was suggestive of lupus) who was receiving danazol in conjunction with corticosteroid therapy. This patient experienced full recovery after stopping danazol in conjunction with the discontinuation of prednisone.

Other complications of steroid injections which are rather 
worrisome are related to dural puncture, infection, damage to the spinal cord, or intrafascicular injection. Dural puncture has been reported following epidural injection, adhesiolysis, paravertebral nerve blocks, lumbar paravertebral sympathetic blocks, and facet joint nerve blocks ( 9 , 102, 181-200). Slucky et al (201) studied the effects of serial epidural injections on the material properties of the lumbar dura mater, as steroids apart from their anti-inflammatory effect also are known to affect collagen synthesis, material strength, and tissue healing. They concluded that serial epidural injections of saline or methylprednisolone at 2-week intervals of three injections produced no significant material or matrix changes in the lumbar dura in canines.

\section{ADMINISTRATION OF STEROIDS}

There is no consensus among interventional pain management specialists or anesthesiologists with regards to either the type and dosage or frequency and total number of injections $(9,24,26)$. The significant attention focused in the literature on the complications attributed to the use of epidural steroids in neural blockade arises from false impressions. Based on the available literature and scientific application, all four formulations of long-acting steroids appear to be safe and effective (Table 2). Consistent with the present literature of pharmacology of steroids, it appears that if repeated within 2 weeks, betamethasone probably would be the best in avoiding side effects, whereas if one treatment is carried out at at least 6 week intervals or longer, any of the four formulations may be used.

Frequency and total number of injections are key issues, although controversial and poorly addressed. Some authors recommend one injection for diagnostic as well as therapeutic purposes; others preach three injections in a series irrespective of patient's progress or lack thereof; still others suggest three injections followed by a repeat course of three injections after 3; 6; or 12- month intervals; whereas others propose an unlimited number of injections with no established goals or parameters. A limitation of $3 \mathrm{mg} / \mathrm{kg}$ of body weight of steroid or $210 \mathrm{mg} / \mathrm{year}$ in an average person and a lifetime dose of $420 \mathrm{mg}$ of steroid also has been advocated. While some investigators recommend one injection and do not repeat if there has been no response to the first, others recommend one or two more injections in the absence of response to the first injection. Warr et al (202) reported that 84 of 144 previously unresponsive patients improved after an additional 1 or 2 injections. Brown (203) believed that more than 3 injections do not result in additional improvement. However, Jurmand (204) reported use of up to 6 injections if they are of benefit, however not to exceed 3 if they are not beneficial. Ito (205) described the use of up to 10 injections. Hickey (206) showed that only $17 \%$ of 250 patients noted benefit with the first epidural steroid injection consisting of $120 \mathrm{mg}$ of methylprednisolone and $7 \mathrm{~mL}$ of saline at the level of spinal pathology and yet a second injection 2 weeks later added $44 \%$ more patients to the improved category, and with a third epidural steroid injection, the remaining 39\%. The concept of additive benefit from serial epidural steroid injections is supported by both Warr et al (202) and Hickey (206).

There are no such descriptions for blocks other than epidural steroids. However, the extrapolation of the limitations described for epidural steroids injections to nerve blocks has been carried out.

\section{CONCLUSION}

Chronic pain is a major health care and social problem. It is no secret that chronic pain is misunderstood by physicians and insurers alike. Neuraxial blockade is an effective modality of treatment in managing chronic pain. Much of the confusion surrounding neural blockade and its side effects in managing chronic pain results from overemphasis on the biopsychosocial model, inappropriate selection of patients for this treatment modality, lack of understanding of the pathophysiology of pain, and inappropriate application of neural blockade in this condition. Corticosteroids in neuraxial blockade are an important adjuvant. These drugs have been proven to be safe when administered carefully.

\section{REFERENCES}

1. Coursin DB, Wood KE. Corticosteroid supplementation for adrenal insufficiency. JAMA 2002; 287:236240.

2. Hench PS, Slocum CH, Polley HF et al. Effect of cortisone and pituitary adrenocorticotrophic hormone (ACTH) on rheumatic diseases. JAMA 1950; 144:1327-1335.

3. Orth DN, Kovacs WJ. In Wilson JD, Foster DW, Kronenberg HM et al (eds). Williams Textbook of Endocrinology, ed 9. WB Saunders Co., Philadelphia, 1998:517-665.

4. Robechhi A., Capra R. L'idrocortisone (composto F). Prime esperienze cliniche in campo reumatologico. Minerva Med 1952; 98:1259-1263.

5. Lievre JA, Bloch-Michel H, Pean G, et al. L'hydrocortisone en injection locale. Rev Rhum 1953; 
20:310-311.

6. Fraser CG, Preuss FS, Bigford WD. Adrenal atrophy and irreversible shock associated with cortisone therapy. JAMA 1952; 149:1542-1543.

7. Lewis L, Robinson RF, Yee J et al. Fatal adrenal cortical insufficiency precipitated by surgery during prolonged continuous cortisone infusion. Ann Intern Med 1953; 39:116-125.

8. Goebert HW, Jallo SJ, Gardner WJ et al. Painful radiculopathy treated with epidural injections of procaine and hydrocortisone acetate results in $113 \mathrm{pa}-$ tients. Anesth Analg 1961; 140:130-134.

9. Bogduk N, Christophidis N, Cherry D, et al. Epidural Use of Steroids in the Management of Back Pain. Report of Working Party on Epidural Use of Steroids in the Management of Back Pain. National Health and Medical Research Council Commonwealth of Australia, Canberra 1994, pp 1-76.

10. Mooney V, Robertson J. The facet syndrome. Clin Orthop 1976; 115:149-156.

11. Sicard MA. Les injections medicamenteuse extraduraqles per voie saracoccygiene. Comptes Renues des Senances de la Societe de Biolgie et de ses Filliales 1901; 53:396-398.

12. Pasquier NM, Leri D. Injection intra-et extradurales de cocaine a dose minime daus le traitment de la sciatique. Bull Gen Ther 1901; 142:196.

13. Cathelin F. Mode d'action de a cocaine injete daus l'escapte epidural par le procede du canal sacre. Comptes Rendies des Senaces de la Societe de Biologic et de ses Filliales 1901; 53:452-453.

14. Caussade G, Queste P. Traitement de al neuralgie sciatique par la mèthode de Sicard. Rèsultats favorables même dans les cas chroniues par la cocaïne à doses élevées et répétées à intervalles raproches. Bull Soc Med Hosp Paris 1909; 28:865.

15. Jacobsen L, Mariano A, Chabal C et al. Beyond the needle. Expanding the role of anesthesiologist in the management of chronic non-malignant pain. Anesthesiology 1997; 87:1210-1218.

16. Ruben JE. Experience with a pain clinic. Anesthesiology 1951; 5:574-582.

17. Manchikanti L, Bakhit CE. Percutaneous lysis of epidural adhesions. Pain Physician 2000; 3:46-64.

18. Manchikanti L, Saini B, Singh V. Spinal endoscopy and lysis of epidural adhesions in the management of chronic low back pain. Pain Physician 2001; 4:240265.

19. Cappio M. Il trattamento idrocortisonico per via epidurale sacrale delle lombosciatalgie. Reumatismo 1957; 9:60-70.

20. McLain RF. Epidural corticosteroid therapy for back and leg pain: Questions of efficacy and action. Pain Digest 1996; 6:153-160.

21. Kappis M. Ueber leitungsanasthesie an Bauch, Burst, Arm und Hals durch Injektion ans Foramen intervertebrale. Munch med Wochenschr 1912; 1:794. 22. Lindholm R, Salenius P. Caudal, epidural administration of anesthetics and corticoids in the treatment of low back pain. Acta Orthop Scand 1964; 1:114-116.

23. Barry PJC, Kendall PH. Corticosteroid infiltration of the extradural space. Ann Phys Med 1962; 6:267-273.

24. Weinstein SM, Herring SA, Derby R. Epidural steroid injections. Spine 1995; 20:1842-1846.

25. Ryan MD, Taylor TKF. Management of lumbar nerveroot pain. Med J Aust 1981; 2:532-534.

26. Manchikanti L. The role of neural blockade in management of low back pain. Pain Digest 1999; 9:166181.

27. Dilke TFW, Burry HC, Grahame R. Extradural corticosteroid injection in management of lumbar nerve root compression. Brit Med J 1973; 2:635-637.

28. Ridley MG, Kingsley GH, Gibson T et al. Outpatient lumbar epidural corticosteroid injection in the management of sciatica. Brit J Rheumatol 1988; 27:295299.

29. Snoek W, Weber H, Jorgensen B. Double blind evaluation of extradural methyl prednisolone for herniated lumbar discs. Acta Orthop Scand 1964; 1:114-116.

30. Manchikanti L. The value and safety of steroids in neural blockade. Part I. AJPM 2000; 10:69-78.

31. Manchikanti L. The value and safety of steroids in neural blockade. Part II. AJPM 2000; 10:122-134.

32. Lindhal O, Rexed B. Histologic changed in spinal nerve roots of operated cases of sciatica. Acta Orthop Scand 1951; 20:215-225.

33. Gertzbein SD. Degenerative disk disease of the lumbar spine. Immunological Implications. Clin Orthop 1977; 129:68-71.

34. Gertzbein SD, Tile M, Gross A et al. Autoimmunity in degenerative disk disease of the lumbar spine. Orthop Clin North Am 1975; 6:67-73.

35. Irsigler FJ. Mikroskopische Befunde in den Ruckenlarkswurzeln beim lumbalen und lumbosakralen (dorsolateral) Diskusprolaps. Acta Neurochi (Wien) 1951; 1:478-516.

36. Lindblom K, Rexed B. Spinal nerve injury in dorsolateral protrusions of lumbar disks. J Neurosurg 1949; 5:413-432.

37. Marshall LL, Trethewie ER. Chemical irritation of nerve-root in disc prolapse. Lancet 1973; 2:320.

38. Marshall LL, Trethewie EW, Curtain CC. Chemical radiculitis. A clinical, physiological, and immunological study. Clin Orthop 1977; 129:61-67.

39. McCarron RF, Wimpee MW, Hudkins PG et al. The inflammatory effect of nucleus pulposus: A possible element in the pathogenesis of low back pain. Spine 1987; 12:758-764.

40. Murphy RW. Nerve roots and spinal nerves in degenerative disk disease. Clin Orthop 1977; 129:46-60.

41. Saal JS, Franson RC, Dobrow R et al. High levels of inflammatory phospholipase A2 activity in lumbar disc 
herniations. Spine 1990; 15:674-678.

42. Park WW, Watanabe RYO. The intrinsic vasculature of the lumbosacral spinal nerves. Spine 1985; 10:508515 .

43. Kayama S, Konno S, Olmarker K et al. Incision of the annulus fibrosus induces nerve root morphologic, vascular, and functional changes. Spine 1996; 21:25392543.

44. Rydevik B, Brown MD, Ludborg G. Pathoanatomy and pathophysiology of nerve root compression. Spine 1984; 9:7-15.

45. Chaoyang C, Cavanaugh JM, Ozaktay C et al. Effects of phospholipase $\mathrm{A}_{2}$ on lumbar nerve root structure and function. Spine 1997; 22:1057-1064.

46. Ozawa K, Atsuta Y, Kato T. Chronic effects of the nucleus pulposus applied to nerve roots on ectopic firing and conduction velocity. Spine 2001; 26:26612665.

47. Anzai H, Hamba M, Onda A et al. Epidural application of nucleus pulposus enhances nociresponses of rat dorsal horn neurons. Spine 2002; 27:E50-E55.

48. Ariga K, Yonenobu K, Nakase T et al. Localization of cathepsins D, $\mathrm{K}$ and $\mathrm{L}$ in degenerated human intervertebral discs. Spine 2001; 26:2666-2672.

49. Fox AJ, Melzack R. Transcutaneous electrical stimulation to acupuncture. Comparison of treatment of low back pain. Pain 1976; 2:141-148.

50. Fowler RJ, Blackwell GJ. Anti-inflammatory steroid induced biosynthesis of a phospholipase $\mathrm{A}_{2}$ inhibitor which prevents prostaglandin generation. Nature 1979; 278:456-459.

51. Devor M, Govrin-Lippmann R, Raber P. Corticosteroids suppress ectopic neural discharges originating in experimental neuromas. Pain 1985; 22:127-137.

52. Hua SY, Chen YZ. Membrane receptor-mediated electrophysiological effects of glucocorticoid on mammalian neurons. Endocrinology 1989; 124:687-691.

53. Johansson A, Hao J, Sjolund B. Local corticosteroid application blocks transmission in normal nociceptor C-fibers. Acta Anaesthesiol Scand 1990; 34:335-338.

54. Faber LE, Wakim NG, Duhring JL. Evolving concepts in the mechanism of steroid action: Current developments. Am J Obstet Gynecol 1987; 156:1449-1458.

55. Olmarker K, Byrod G, Cornefijord M et al. Effects of methylprednisolone on nucleus pulposus-induced nerve root injury. Spine 1994; 19:1803-1808.

56. Nicol GD, Klingberg DK, Vasko MR. Prostaglandin E2 enhances calcium conductance and stimulates release of substance $\mathrm{P}$ in avian sensory neurons. $J$ Neurosci 1992; 12:1917-1927.

57. Coderre T. Contribution of protein kinase $\mathrm{C}$ to central sensitization and persistent pain following tissue injury. Neurosci Lett 1992; 140:181-184.

58. Hayashi N, Weinstein JN, Meller ST et al. The effect of epidural injection of betamethasone or bupivacaine in a rat model of lumbar radiculopathy. Spine 1998;
23:877-885.

59. Lee HM, Weinstein JN, Meller ST et al. The role of steroids and their effects on phospholipase $\mathrm{A}_{2}$. An animal model of radiculopathy. Spine 1998; 23:11911196.

60. Minamide A, Tamaki T, Hashizume $\mathrm{H}$ et al. Effects of steroids and lipopolysaccharide on spontaneous resorption of herniated intervertebral discs. An experience study in the rabbit. Spine 1998; 23:870-876.

61. Johansson A, Bennett GJ. Effect of local methylprednisolone on pain in a nerve injury model. A pilot study. Reg Anesth 1997; 22:59-65.

62. Kingery WS, Castellote JM, Maze M. Methylprednisolone prevents the development of autotomy and neuropathic edema in rats, but has no effect on nociceptive thresholds. Pain 1999; 80:555-566.

63. Abram SE, Hopwood MB. What factors contribute to outcome with lumbar epidural steroids? In Bond MR, Charlton JE, Woolf CJ (eds). Proceedings of the VIth World Congress on Pain. Elsevier Publications, Amsterdam, 1991, pp 495-500.

64. Zaloga GP, Marik P. Hypothalamic-pituitary-adrenal insufficiency. Crit Care Clin 2001; 17:25-41.

65. Saito T, Takanashi M, Gallagher E et al. Corticosteroid effect on early beta-adrenergic down-regulation during circulatory shock: Hemodynamic study and beta-adrenergic study. Intensive Care Med 1995; 21:204-210.

66. Diederich S, Baehr V, Oelkers W. Therapie der Nebennierenrindeninsuffizienz. Dtsch Med Wochenschr 1994; 119:595-597.

67. Esteban NV, Loughlin T, Yergey A et al. Daily cortisol production in man determined by stable isotope dilution/mass spectrometry. J Clin Endocrinol Metab 1991; 72:39-45.

68. Krasner AS. Glucocorticoid-induced adrenal insufficiency. JAMA 1999; 282:671-676.

69. Lamberts SWJ, Bruining HA, DeJong FH. Corticosteroid therapy in severe illness. N Engl J Med 1997; 337:1285-1292.

70. McEvoy GK, Litvak K, Welsh OH et al. AHFS 99 Drug Information. Bethesda, American Society of Health-System Pharmacists, 1999, pp 2636-2662.

71. Jacobs A, Pullan PT, Potter JM et al. Adrenal suppression following extradural steroids. Anaesthesia 1983; 38:953-956.

72. Kay JK, Findling JW, Raff H. Epidural triamcinolone suppresses the pituitary-adrenal axis in human subjects. Anesth Analg 1994; 79:501-505.

73. Janicki PK, Johnson B, Parris WC. Pharmacokinetic analysis of plasma methylprednisolone after administration in rabbits. Proceedings of the American Society of Regional Anesthesia, Annual Meeting, 1995, 7.

74. Hsu D, Fu P, Gyermek L, Tan C. Comparison of plasma cortisol and ACTH profile after a single lumbar epidural dose of triamcinolone $40 \mathrm{mg}, 80 \mathrm{mg}$ respectively 
in low back pain patients. Anesth Analg 1996; 82:S191.

75. Mikhail GR, Sweet LC, Mellinger RC. Parenteral longacting corticosteroid effect on hypothalamic pituitary adrenal function. Ann Allergy 1973; 31:337-343.

76. Mikhail GR, Livingood CS, Mellinger RC et al. Effect of long-acting parenteral corticosteroids on adrenal function. Arch Dermatol 1969; 100:263-268.

77. Schimmer BP, Parker KL. Adrenocorticotropic hormone; adrenocortical steroids and their synthetic analogs; inhibitors of the synthesis and actions of adrenocortical hormones In Hardman JG, Molinoff PB, Ruddon RW (eds). Goodman's \& Gilman's, The Pharmacological Basis of Therapeutics; ed 9., McGrawHill, New York, 1996, pp 1459-1485.

78. LaRochelle GE, LaRochelle AG, Ratner RE et al. Recovery of the hypothalamic-pituitary-adrenal axis in patients with rheumatic diseases receiving low-dose prednisone. Am J Med 1993; 326:258-264.

79. Oelkers W. The role of high- and low-dose corticotropin tests in the diagnosis of secondary adrenal insufficiency. Eur J Endocrinol 1998; 139:567-570.

80. Nelson D. Dangers from methylprednisolone acetate therapy by intraspinal injection. Arch Neurol 1988; 45:804-806.

81. Wilkinson HA. Intrathecal Depo-Medrol. A literature review. Clin J Pain 1992; 8:49-56.

82. Corrigan AB, Carr G, Tugwell S. Intraspinal corticosteroid injections. Med J Aust 1982; 1:224-225.

83. Bogduk N, Cherry D. Epidural corticosteroid agents for sciatica. Med J Aust 1985; 143:402-406.

84. Nelson DA. Intraspinal therapy using methylprednisolone acetate. Spine 1993; 18:278-286.

85. Hurst EW. Adhesive arachnoiditis and vascular blockage caused by detergents and other chemical irritants. An experimental study. Neurology 1961; 11:251-256.

86. Margolis G, Hall HE, Nowill WK. An investigation of efocaine, a long-acting local anesthetic agent. I. Animal studies. Arch Surg 1953; 67:715-730.

87. Chino N, Awad EA, Kottke FJ. Pathology of propylene glycol administered by perineural and intramuscular injection in rats. Arch Phys Med Rehab 1974; 55:33-38.

88. Benzon HT, Gissen AJ, Strichartz GR et al. The effect of polyethylene glycol on mammalian nerve impulses. Anesth Analg 1987; 66:553-559.

89. Feasby TE, Hahn AF, Gilbert JJ. Neurotoxicity of bacteriostatic water. N Engl J Med 1983; 308:966967.

90. Craig DB, Habib GG. Flaccid paraparesis following obstetrical epidural anesthesia. Possible role of benzyl alcohol. Anaesth Analg 1977; 56:219-222.

91. Saiki JH, Thompson S, Smith F et al. Paraplegia following intrathecal chemotherapy. Cancer 1972; 29:370-374.

92. Hahn AF, Feasby TE, Gilbert JJ. Paraparesis following intrathecal chemotherapy. Neurology 1983;
33:1032-1038

93. Bagshawe KD, Magrath IT, Golding PR. Intrathecal methotrexate. Lancet 1969; 2:1258.

94. Hornfeldt CS, Larson AA. Seizures induced by fluoroacetic acid and fluorocitric acid may involve chelation of divalent cations in the spinal cord. Eur $J$ Pharmacol 1990; 179:307-313.

95. Goto S, Grosfeld JL. The effect of neurotoxin (benzalkonium chloride) on the lower esophagus. J Surg Res 1989; 47:117-119.

96. Holle GE. Changes in the structure and regeneration mode of the rat small intestinal mucosa following benzalkonium chloride treatment. Gastroenterology 1991; 101:1264-1273.

97. Latham JM, Fraser RD, Moore RJ et al. The pathologic effects of intrathecal betamethasone. Spine 1997; 22:1558-1562.

97. Abram SE, Marsala M, Yaksh TL. Analgesic and neurotoxic effects of intrathecal corticosteroids in rats. Anesthesiology 1994; 81:1198-1205.

99. Delaney TJ, Rowlingson JC, Carron $\mathrm{H}$ et al. Epidural steroid effects on nerves and meninges. Anesth Analg 1980; 58:610-614.

100. Cicala RS, Turner R, Moran E et al. Methylprednisolone acetate does not cause inflammatory changes in the epidural space. Anesthesiology 1990; 72:556-558. MacKinnon SE, Hudson AR, Gentilli R et al. Peripheral nerve injection injury with steroid agents. Plast Reconstr Surg 1982; 69:482-489.

102. Abram SE, O'Connor TC. Complications associated with epidural steroid injections. Reg Anesth 1996; 212:149-162.

103. Hashimoto K, Sakura S, Bollen AW et al. Comparative toxicity of glucose and lidocaine administered intrathecally in the rat. Reg Anes and Pain Med 1998; 23:444-450.

104. Katz JA, Sehlhorst S, Blisard KS. Histopathologic changes in primate spinal cord and single repeated epidural phenol administration. Reg Anesth 1995; 20:283-290.

105. Melby JC. Drug spotlight program: systemic corticosteroid therapy; pharmacologic and endocrinologic considerations. Ann Intern Med 1974; 81:505-512.

106. Knight CL, Burnell JC. Systemic side-effects of extradural steroids. Anaesthesia 1980; 35:593-594.

107. Stambough JL, Booth RE, Rothman RH. Transient hypercorticism after epidural steroid injection. J Bone and Joint Surg 1984; 66-A:1115-1116.

108. Tuel SM, Meythaler JM, Cross LL. Cushing's syndrome from epidural methylprednisolone. Pain 1990; 40:81-84

109. Edmonds LC, Vance ML, Hughes JM. Morbidity from paraspinal Depo-Corticosteroid injections for analgesia. Cushing's syndrome and adrenal suppression. Anesth Analg 1991; 72:820-822.

110. Armstrong RD, English J, Gibson T et al. Serum me- 
thylprednisolone levels following intraarticular injection of methylprednisolone acetate. Ann Rheum Dis 1981; 40:571-574.

111. Hughes JM, Hichens M, Booze GW et al. Cushing's syndromes from therapeutic use of intramuscular dexamethasone acetate. Arch Intern Med 1986; 146:18481849.

112. Oelkers W. Adrenal insufficiency. NEngl J Med 1996; 335:1206-1212.

113. Streck WF, Lockwood DW. Pituitary adrenal recovery following short-term suppression with corticosteroids. Am J Med 1979; 66:910-914.

114. Saberski LR, Fitzgerald J, Landau C et al. Practice patterns in the use of epidural corticosteroid injections. A survey of the Connecticut State Society of Anesthesiologists. Anesthesiology 1998: Poster Exhibits 101.

115. Tarlov E, Wiltse L, Stanton-Hicks M. Therapeutic caudal or epidural block for lower back or sciatic pain. Questions and answers. JAMA 1980; 243:369-370.

116. Gray RG, Gottlieb NL. Intraarticular corticosteroids. An updated assessment. Clin Orthop 1983; 177:235263.

117. Healey JH. Glucocorticoid-induced osteoporosis. Curr Opin Orthop 1994; 5:33-38.

118. Ho YV, Briganti EM, Duan Y et al. Polymorphism of the vitamin $\mathrm{D}$ receptor gene and corticosteroid-related osteoporosis. Osteoporosis Int 1999; 9:134-138.

119. Sambrook PN, Kelly PJ, Keogh A et al. Bone loss after cardiac transplantation: A prospective study. $J$ Heart Lung Transpl 1994; 13:116-121.

120. Reid IR, Heap SW. Determinants of vertebral mineral density in patients receiving long-term glucocorticoid therapy. Arch Intern Med 1990; 150:2545-2548.

121. Morrison NA, Qi JC, Tokita A et al. Prediction of bone density from vitamin D receptor alleles. Nature 1994; 367:284-287.

122. Spector TD, Keen RW, Arden NK et al. Influence of vitamin $\mathrm{D}$ receptor genotypes on bone mineral density in postmenopausal women: A twin study in Britain. Br Med J 1995; 310:1357-1360.

123. Sainz J, Van Tornout JM, Loro ML et al. Vitamin D receptor gene polymorphisms and bone density in prepubertal American girls of Mexican descent. NEngl J Med 1997; 337:77-82.

124. Riggs BL, Nguyen TV, Melton LJ et al. The contribution of vitamin D receptor gene alleles to the determination of bone mineral density in normal and osteoporotic women. J Bone Miner Res 1995; 10:991996.

125. Fleet JC, Harris SS, Wood RJ et al. The BsmI vitamin $\mathrm{D}$ receptor restriction fragment length polymorphism (BB) predicts low bone density in premenopausal black and white women. J Bone Miner Res 1995; 10:985990.

126. Krall EA, Parry P, Lichter JB et al. Vitamin D receptor alleles and rates of bone loss: Influence of years since menopause and calcium intake. J Bone Miner Res 1995; 10:979-984.

127. Yamagata Z, Miyamura T, Iijima S et al. Vitamin D receptor gene polymorphism and bone mineral density in healthy Japanese women. Lancet 1994; 344:1027.

128. Dawson-Hughes B, Harris SS, Finneran S. Calcium absorption on high and low calcium intakes in relation to vitamin D receptor genotype. J Clin Endocrinol Metab 1995; 80:3657-3661.

129. Hustmyer FG, Peacock M, Hui S et al. Bone mineral density in relation to polymorphism at the vitamin D receptor gene locus. J Clin Invest 1994; 94:2130-2134.

130. Garnero P, Borel O, Sornay-Rendu E et al. Vitamin D receptor gene polymorphisms do not predict bone turnover and bone mass in healthy premenopausal women. J Bone Miner Res 1995; 10:1283-1288.

131. Melhus H, Kindmark A, Amer S et al. Vitamin D receptor genotypes in osteoporosis. Lancet 1994; 344:949-950.

132. Spotila LD, Caminis J, Johnson R et al. Vitamin D receptor genotype is not associated with bone mineral density in three ethnic/regional groups. Calcif Tissue Int 1996; 59:235-237.

133. Francis RM, Harrington F, Turnere E et al. Vitamin D receptor gene polymorphism in men and its effect on bone density and calcium absorption. Clin Endocrinol 1997; 46:83-86.

134. Goldstein MF, Fallon JJ, Harning R. Chronic glucocorticoid therapy induced osteoporosis in patients with obstructive lung disease. Chest 1999; 16:1733-1749.

135. Buckley LM, Marquez M, Feezor R et al. Prevention of corticosteroid-induced osteoporosis: Results of a patients survey. Arthritis Rheum 1999; 42;1736-1739. Haugeberg G, Uhlig T, Falch JA et al. Bone mineral density and frequency of osteoporosis in female patients with rheumatoid arthritis. Arthritis Rheum 2000; 43:522-530.

137. Mankin HJ. Nontraumatic necrosis of bone (osteonecrosis). N Engl J Med 1992; 326:1473-1479.

138. Kelman GJ, Williams GW, Colwell CW et al. Steroidrelated osteonecrosis of the knee. Clin Orthop 1990; 257:171-176.

139. Manchikanti L, Pampati VS, Beyer C et al. The effect of neuraxial steroids on weight and bone mass density: A prospective evaluation. Pain Physician 2000; 3:357-366.

140. Cousins MJ. An additional dimension to the efficacy of epidural steroids. Anesthesiology 2000; 93:565.

141. Johns KJ, Chandra SR. Visual loss following intranasal corticosteroid injection. JAMA 1989; 261:2413.

142. Abram S. An additional dimension to the efficacy of epidural steroids. Anesthesiology 2000; 93:566.

143. Pacy PJ, Halliday D. Muscle protein synthesis in steroid-induced proximal myopathy: A case report. Muscle Nerve 1989; 12:378-381. 
144. Janssens S, Decramer M. Corticosteroid-induced myopathy and the respiratory muscles. Report of two cases. Chest 1989; 95:1160-1162.

145. Ruff RL, Weissmann J. Endocrine myopathies. Neurol Clin 1988; 6:575-592.

146. Buskila D, Schleifer E, Odes HS et al. Increased nonarticular tenderness in patients on steroid therapy. Eur $J$ Pain 1998; 2:261-266.

147. Boonen S, Van Distel G, Westhovens R et al. Steroid myopathy induced by epidural triamcinolone injection. Brit J Rheumatol 1995; 34:385.

148. Roy-Camille R, Mazel CH, Husson JL et al. Symptomatic spinal epidural lipomatosis induced by a longterm steroid treatment. Spine 1991; 16:1365-1371.

149. Giuffre R. Intradural spinal lipomas. Review of the literature (99 cases) and report of an additional case. Acta Neurochi 1966; 14:69-95.

150. Fessler RG, Johnson DL, Brown FD et al. Epidural lipomatosis in steroid-treated patients. Spine 1992; 17:183-188.

151. Rawlins BA, Di Giacinto GV. Epidural compression in the spinal canal caused by excessive adipose tissue. A case report. Clin Orthop 1992; 275:140-143.

152. Chen YCJ, Gajraj NM, Clavo A et al. Posterior subcapsular cataract formation associated with multiple lumbar epidural corticosteroid injections. Anesth Analg 1998; 86:1054-1055.

153. Black RL, Oglesby RB, von Stallmann L et al. Posterior subcapsular cataracts induced by corticosteroids in patients with rheumatoid arthritis. JAMA 1960; 174:166-171.

154. Brocklebank JT, Harcourt RB, Meadow SR. Corticosteroid-induced cataracts in idiopathic nephrotic syndrome. Arch Dis Child 1982; 53:30-34.

155. Oglesby RB, Black RL, von Stallmann L et al. Cataracts in patients with rheumatoid arthritis patients treated with corticosteroids. Arch Ophthalmol 1961; 66:519-523.

156. Urban RC, Cotlier E. Corticosteroid-induced cataracts. Surv Ophtalmol 1986; 31:102-110.

157. Skalka HW, Prchal JT. Effect of corticosteroids on cataract formation. Arch Ophthalmol 1980; 98:17731777.

158. Allen MB, Ray SG, Leitch AG et al. Steroid aerosols and cataract formation. Br Med J 1989; 299:432-433.

159. Becker B. Cataracts and topical corticosteroids. Am J Ophthalmol 1964; 58:872-873.

160. Harding JJ, Heyningen RV. Drugs, including alcohol, that act as risk factors for cataract, and possible protection against cataract by aspirin-like analgesics and cyclopenthiazide. Br J Ophthalmol 1988; 72:809-814.

161. Leske MC, Chylack LT, Wu SY. The lens opacities case-control study. Arch Ophthalmol 1991; 109:244251.

162. West SK, Duncan DD, Muñoz B et al. Sunlight exposure and risk of lens opacities in a population-based study. The Salisbury Eye Evaluation Project. JAMA 1998; 280:714-718.

163. Walman GB, Chisholm L, Arbus GS. Cataracts in pediatric renal transplant recipients. Can Med Assoc J 1977; 117:1257-1258.

164. Pavlin CR, DeVeber GA, Cook CT et al. Ocular complications in renal transplant recipients. Can Med Assoc $J$ 1977; 117:360-362.

165. Fournier C, Milot JA, Clermont MJ et al. The concept of corticosteroid cataractogenic factor revisited. Can J Ophthalmol 1990; 25:345-347.

166. Limaye SR, Pillai S, Tina LU. Relationship of steroid dose to degree of posterior subcapsular cataracts in nephrotic syndrome. Ann Ophthalmol 1988; 20:225227.

167. Ling C, Atkinson PL, Munton CG. Bilateral retinal hemorrhages following epidural injection. $\mathrm{Br} J$ Ophthalmol 1993; 77:316-317.

168. Kushner FH, Olson JC. Retinal hemorrhage as a consequence of epidural steroid injection. Arch Ophthalmol 1995; 113:309-313.

169. Purdy EP, Ajimal GS. Vision loss after lumbar epidural steroid injection. Anesth Analg 1998; 86: 119-122.

170. Victory RA, Hassett P, Morrison G. Transient blindness following epidural analgesia. Anesthesia 1991; 46:940-941.

171. Clark CJ, Whitwell J. Intraocular hemorrhage after epidural injection. Br Med J 1961; 2:1612-1613.

172. Usubiaga JE, Wikinski JA, Usubiaga LE. Epidural pressure and its relation to spread of anesthetic solution in epidural space. Anesth Analg 1967; 46:440446.

173. Morris DA, Henkind P. Relationship of intracranial, optic-nerve sheath and retinal hemorrhage. Am J Ophthalmol 1967; 64:853-859.

174. De Sio JM, Kahn CH, Warfield CA. Facial flushing and/or generalized erythema after epidural steroid injection. Anesth Analg 1995; 80:617-619.

175. Trattner A, Hodak E, David M et al. Kaposi's sarcoma with visceral involvement after interarticular and epidural injections of corticosteroids. J Am Acad Dermatol 1993; 29:890-894.

176. Katz JA, Lukin R, Bridebaugh PO et al. Subdural intracranial air. An unusual case of headache after epidural steroid injection. Anesthesiology 1991; 74:615618.

177. Thomson SJ, Lomax DM, Collett BJ. Chemical meningism after lumbar facet joint block with local anesthetic and steroids. Anesthesia 1992; 47:905-906.

178. Aoki M, Kato F, Mimatsu K et al. Histologic changes in the intervertebral disc after intradiscal injections of methylprednisolone acetate in rabbits. Spine 1997; 22:127-132.

179. Awong IE, Dandurand KR, Keeys CA et al. Drugassociated Guillain-Barré syndrome: A literature review. Ann Pharmacotherapy 1996; 30:173-180. 
180. Steiner I, Itzhak W, Abramsky O. Appearance of Guillain-Barré syndrome in patients during corticosteroid treatment. J Neurol 1986; 233:221-223.

181. Schmidt SD, Gibbons JJ. Post dural puncture headache after fluoroscopically guided lumbar paravertebral sympathetic block. Anesthesiology 1993; 78:198200.

182. Gladstone JC, Pennant JH. Spinal anesthesia following facet joint injection. Anaesthsia 1987; 42:754-756.

183. Aldrete JA, Zapata JC, Ghaly R. Arachnoiditis following epidural adhesiolysis with hypertonic saline report of two cases. Pain Digest 1996; 6:368-370.

184. Marks R, Semple AJ. Spinal anesthesia after facet joint injection. Anaesthesia 1988; 43:65-66.

185. Waldman SD. Complications of cervical epidural nerve blocks with steroids. A prospective study of 790 consecutive blocks. Reg Anesth 1989; 14:149-151.

186. Auroy Y, Narchi P, Messiah A et al. Serious complications related to regional anesthesia. Results of a prospective survey in France. Anesthesiology 1997; 87:479-486.

187. Bromage PR. Complications and contraindications. In. Bromage PR (ed). Epidural Analgesia. Philadelphia, WB Saunders, 1978, pp 469-471.

188. Bromage PR, Benumof JL. Paraplegia following intracord injection during attempted epidural anesthesia under general anesthesia. Reg Anesth Pain Med 1998; 23:104-107.

189. Krane EJ, Dalens BJ, Murat I et al. The safety of epidurals placed during general anesthesia. Reg Anesth Pain Med 1998; 23:433-438.

190. Hodges SC, Castleberg RL, Miller T et al. Cervical epidural steroid injection with intrinsic spinal cord damage. Spine 1998; 23:2137-2142.

191. Derby R. Cervical epidural steroid injection with intrinsic spinal cord damage. Point of view. Spine 1998; 23:2141-2142.

192. Saberski LR, Kondamuri S, Osiniubi OYO. Identification of the epidural space. Is loss of resistance to air a safe technique? Regional Anesthesia 1997; 22:3-
15.

193. Junila J, Niinimaki T, Tervonen O. Epidural abscess after lumbar discography. Spine 1997; 18:2191-2193.

194. Waldman SD. Cervical epidural abscess after cervical epidural nerve block with steroids. Anesth Analg 1991; 72:717-718.

195. Bromage PR. Spinal extradural abscess: Pursuit of vigilance. Brit J Anaesth 1993; 70:471-473.

196. Strong WE. Epidural abscess associated with epidural catheterization: A rare event? Report of two cases with markedly delayed presentation. Anesthesiology 1991; 74:943-946.

197. Bollensen E, Prange HW. An epidural spinal abscess as a lethal complication of peridural anesthesia. Reg Anaesth 1991; 14:101-103.

198. Schaerer JP. Cervical discography. J Int Coll Surg 1964; 42:287-296.

199. Schiller F, Shadle OW. Extrathecal and intrathecal suppuration. Arch Neurol 1962; 7:33-36.

200. Vogelsang H. Discitis intervertebralis cervicalis nach diskographie. Neurochirurgia 1973; 16:80-83.

201. Slucky AV, Sacks MS, Pallares VS et al. Effects of epidural steroids on lumbar dura material properties. J Spinal Dis 1999; 12:331-340.

202. Warr AC, Wilkinson JA, Burn JMB et al. Chronic lumbosciatica syndrome treated by epidural injection and manipulation. Practitioner 1977; 209:53-59.

203. Brown FW. Management of discogenic pain using epidural and intrathecal steroids. Clin Ortho 1977; 129:72-78.

204. Jurmand SH. Corticotherapie peridurale des lombalgies et des sciatiques d'origine disclae. Concours Medicale 1972; 94:5061-5070.

205. Ito $\mathrm{R}$. The treatment of low back pain and sciatica with epidural corticosteroids injection and its pathophysiologic basis. J Jpn Orthop Assoc 1971; 45:769777.

206. Hickey RF. Outpatient epidural steroid injections for low back pain and lumbosacral radiculopathy. NZMed J 1987; 100:54-59. 